\title{
Feminist and masculine values and their effects on female managerial positions in nonprofit and corporate public relations
}

Sarah E. Thomas

West Virginia University

Follow this and additional works at: https://researchrepository.wvu.edu/etd

\section{Recommended Citation}

Thomas, Sarah E., "Feminist and masculine values and their effects on female managerial positions in nonprofit and corporate public relations" (2005). Graduate Theses, Dissertations, and Problem Reports. 1582.

https://researchrepository.wvu.edu/etd/1582

This Thesis is protected by copyright and/or related rights. It has been brought to you by the The Research Repository @ WVU with permission from the rights-holder(s). You are free to use this Thesis in any way that is permitted by the copyright and related rights legislation that applies to your use. For other uses you must obtain permission from the rights-holder(s) directly, unless additional rights are indicated by a Creative Commons license in the record and/ or on the work itself. This Thesis has been accepted for inclusion in WVU Graduate Theses, Dissertations, and Problem Reports collection by an authorized administrator of The Research Repository @ WVU. For more information, please contact researchrepository@mail.wvu.edu. 


\title{
Feminist and Masculine Values and Their Effects on Female Managerial
} Positions in Nonprofit and Corporate Public Relations

\section{Sarah E. Thomas}
Thesis Submitted to the School of Journalism
at West Virginia University
in partial fulfillment of the requirements
for the degree of

\author{
Master of Science \\ in \\ Journalism
}
Dr. Terry Wimmer, Chair
Dr. Ivan Pinnell
Dr. George Esper
Dr. Carol Zwickel

\section{Morgantown, WV 2005}

Keywords: Feminist Theory, Masculine Values, Feminist Values, Public Relations

Copyright 2005 Sarah E. Thomas 


\begin{abstract}
Feminist and Masculine Values and Their Effects on Female Managerial

Positions in Nonprofit and Corporate Public Relations
\end{abstract}

Sarah E. Thomas

This study examines the rise of executive women in public relations in both the nonprofit and corporate sectors. The focus of this study was on feminist and masculine values and their effects on female executives. A survey of 121 female executives from the corporate, nonprofit, and agency settings was conducted to analyze their views on feminist and masculine values in public relations and their effects on managerial positions. Results indicated that women who place greater value on masculine traits are more likely to obtain management positions in the corporate sector. Those who place greater value on feminist values do not necessarily elevate to positions of leadership in the nonprofit sector. Also, women believe men are lacking feminist traits, whole women contain both masculine and feminine traits. 


\section{CONTENTS}

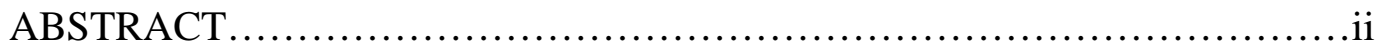

LIST OF TABLES.......................................................

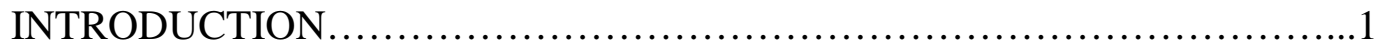

RESEARCH QUESTION.......................................................

LITERATURE REVIEW ................................................

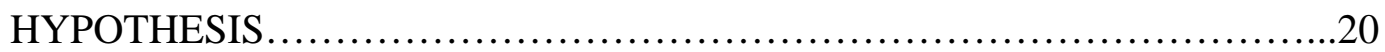

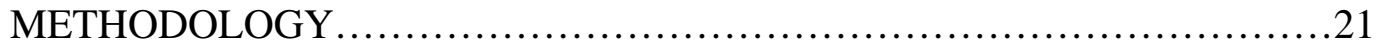

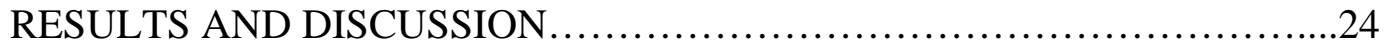

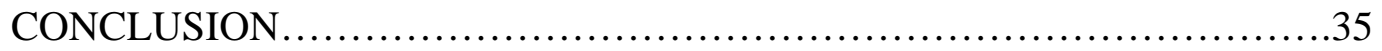

SELECTED BIBLIOGRAPHY ...........................................

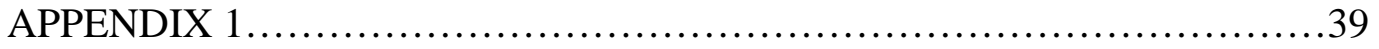




\section{TABLES}

Table

Page

1.1. Years Worked in Public Relations.......................................25

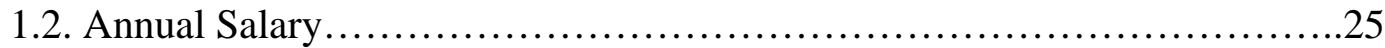

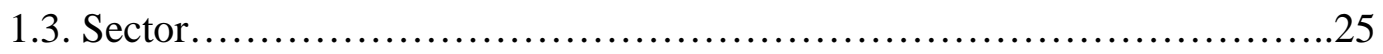

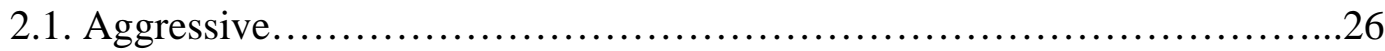

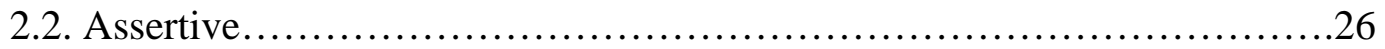

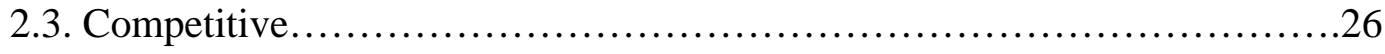

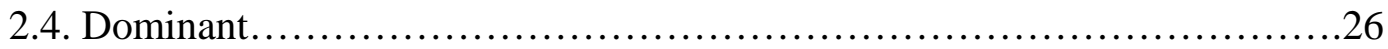

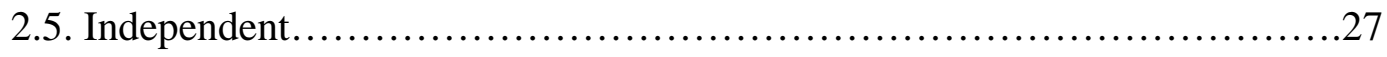

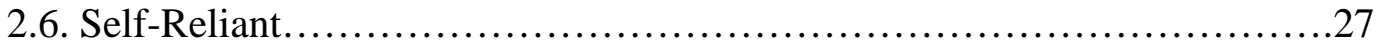

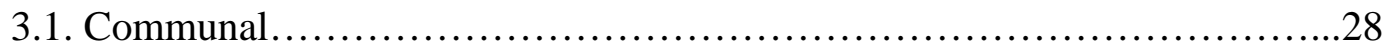

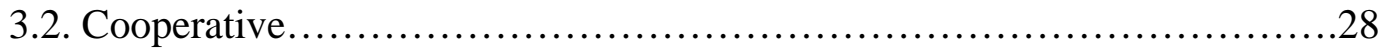

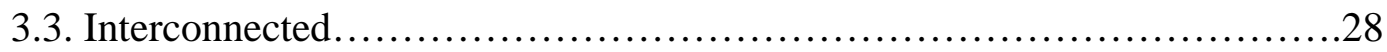

3.4. Perceptive.......................................................... 28

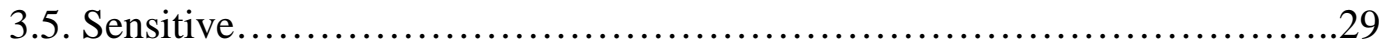

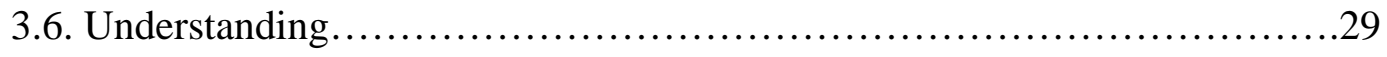

4.1. Women have a relatively easier time elevating to positions of leadership in nonprofit organizations than corporate organizations........30

4.2. It is easier for women to enter executive and managerial jobs in sectors in which they predominately supervise women...................30

4.3. Women who are sensitive, honest, and tolerant are more likely to become executives in the nonprofit sector............................31 


\section{TABLES (continued)}

Table

Page

5.1. The attributes of a good public relations executive are self-reliant, aggressive, and independent

5.2. Our society and culture places higher importance on

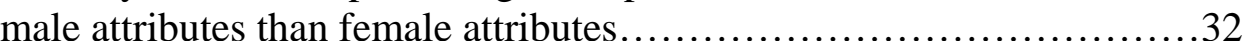

5.3. The higher social and economic status of men in our society

is a result of society placing higher importance on

male attributes than female attributes

5.4. I feel more respected when I am assertive, dominant, and self-confident while performing managerial tasks.....................32

5.5. Women who are aggressive, dominant, and competitive are more likely to become executives in the corporate sector.

6.1. To be a successful public relations executive, women must display more masculine qualities.

6.2. To be a successful public relations executive, women must suppress their feminine traits 


\section{INTRODUCTION}

The field of public relations is considered a gendered occupation. Today, women comprise nearly 70 percent of the public relations profession. ${ }^{1}$ When the Public Relations Journal began in 1945, women were officially recognized as public relations practitioners. They were initially accepted into the profession because there were few barriers for entry into the field. ${ }^{2}$

Grunig, Toth and Childers define public relations as "the organizational function responsible for establishing and maintaining relationships with the public.”3 ${ }^{\text {There has been }}$ much debate as to why such a large number of women enter the public relations profession. In his 1968 research, Smith suggests that "public relations is a highly intuitive business" which is a "talent inborn in little girls." ${ }^{4}$ Bates believed that the high number of women in the profession is due to the fact that "women have better instincts... a different sensitivity to the communication needs of people and institutions and are therefore better suited for the practice.” ${ }^{5}$

These same attributes are often used when describing the nonprofit sector. An especially high number of women work for nonprofit organizations. The nonprofit sector plays a major role in the lives of American women, and they play a major role in and throughout the nonprofit sector. ${ }^{6}$ As a result, the nonprofit sector is considered "gendered female."7 The symbols,

\footnotetext{
${ }^{1}$ Linda Aldoory and Elizabeth Toth, “Gendered Profession: A Developing Theory for Public Relations,” Journal of Public Relations Research 14, no. 2 (2002):103.

${ }^{2}$ Karla H. Gower, “Rediscovering Women in Public Relations,” Journalism History 27, no. 1 (Spring 2001): 14.

${ }^{3}$ Larissa A. Grunig, Elizabeth L. Toth, and Linda Childers Hon, “Feminist Values in Public Relations,” Journal of Public Relations Research 12, no. 1 (January 2000): 1.

${ }^{4}$ R. Smith, “Women in Public Relations,” Public Relations Journal 24 (1968): 26.

${ }^{5}$ D. Bates, “A Concern: Will Women Inherit the Profession?” Public Relations Journal 29 (1983): 6.

${ }^{6}$ Teresa Odendahl and Michael O’Neill, Women \& Power in the Nonprofit Sector, (CA: Jossey-Bass Inc., 1994), 15. ${ }^{7}$ Ibid., 14.
} 
images, values, and typical activities of the sector are "female" and "soft"- providing service, being concerned with morality and ethics, producing beauty, and helping people. ${ }^{8}$

There are nearly 5 million women employees of the nonprofit sector and 50 million

women volunteers. ${ }^{9}$ Of the 5 million women employees, 592,000 held executive, administrative, and managerial positions in $1990 .^{10}$ Comparing this with the 431,000 male nonprofit employees who held such positions, women comprised 58 percent of these positions in the nonprofit sector in $1990 .^{11}$

Although women hold the majority of executive and managerial positions in the nonprofit sector, they are still affected by a glass ceiling when it comes to how much they are paid. The same is true with the field of public relations.

\section{PURPOSE}

With these truths about women in public relations and the nonprofit sector, the author hopes to provide a better insight into the reasons why women enter such fields. Areas such as education, gender discrepancy, masculine and feminine values, values of nonprofit organizations and leadership roles will be examined in an attempt to illuminate the motivation of women in public relations and the nonprofit sector.

\footnotetext{
${ }^{8}$ Ibid.

${ }^{9}$ Ibid., 15.

${ }^{10}$ Ibid., 12.

${ }^{11}$ Ibid.
} 


\section{RESEARCH QUESTION}

What is feminist theory and how are women perceived in both public relations and the nonprofit workforce?

\section{LITERATURE REVIEW}

This literature review seeks to answer the foregoing research question by focusing on the existing literature relevant to four key concepts underlying the study. The key elements include: gender roles and values, leadership roles of men and women, and the nonprofit sector and female management. It will also provide a theoretical framework behind the rise of women in the nonprofit workforce. The review is organized into four sections: (1) Feminist theory and the rise of women in the nonprofit workforce, (2) gender roles and values in public relations, (3) leadership roles of men and women, and (4) the nonprofit sector and female managers.

The basis of women in the nonprofit workforce can be linked to a theory that explores the connection between feminine gender and feminist values. According to Shapiro, "Feminist theory points simultaneously to the ways in which the exclusion of women has shaped professional practices and to the effects, within the knowledge of each discipline, of socially and historically constructed gender identities.”12 Feminist theorists have two main goals: (1) “reclaim the identity of 'woman' and to give it political meaning,” and (2) "settle within an identity that has 'an all too solid history'.”13 There is a distinctive woman’s culture inflected by values generated in women's relationships with each other or through their traditional female roles and activities. ${ }^{14}$

\footnotetext{
${ }^{12}$ Ann-Louise Shapiro, "Introduction: History and Feminist Theory, or Talking Back to the Beadle,” History \& Theory 31, no. 4 (December 1992): 1.

${ }^{13}$ Ibid., 4.

${ }^{14}$ Ibid.
} 
Based on the broad range of feminist theory, Shapiro states, "There is obviously no single feminist theory. And neither is there an easy way to incorporate the necessary attentiveness to difference that feminism espouses - differences of ethnicity, sexuality and nationality, as well as gender, race, and class - within a single theoretical framework." ${ }^{\prime 15}$ In essence, feminist theory is a compilation of ideas. Just as every woman is different and possesses different attributes, so does feminist theory.

Women have had a reigning role in the nonprofit sector throughout American history. Women have found in the nonprofit sector opportunities for leadership, power, and influence not available to them in the business and government sectors. For example, women in nonprofit organizations have played a major role in shaping public policy in the nineteenth and twentieth centuries in areas such as women's political and economic rights and child welfare. At the local level, women have exercised leadership in thousands of arts, social service, religious, and other nonprofit organizations. ${ }^{16}$

According to Odendahl and O'Neill, most charitable organizations in the seventeenth, eighteenth, nineteenth, and early twentieth centuries were led and controlled by men. There were exceptions, however. A few upper-class, Anglo-Saxon Protestant women pioneered the feminist movement: Elizabeth Cady Stanton and the women's suffrage movement; Jane Adams and social work as a profession; Dorothea Dix and mental health reformation, Clara Barton, founder of the American Red Cross; Mary Baker Eddy, Ellen Gould White, and Mother Elizabeth Ann Seton in religion; Emma Willard, Catherine Beecher, and Mary Lyon in private

\footnotetext{
${ }^{15}$ Ibid., 7.

${ }^{16}$ Odendahl and O’Neill, Women \& Power in the Nonprofit Sector, 1-2.
} 
education; and Isabella Stewart Gardner in support of the arts. ${ }^{17}$ In more recent times, the accomplishments of women throughout the nonprofit sector have helped vast areas of American life such as: women’s and children’s rights, minority rights, environmentalism, the peace movement, and the pro-choice movement. ${ }^{18}$

The nonprofit sector has always been a major employer of women. While the workforce participation of women has been steadily increasing in the twentieth century, the passage of the Civil Rights Act of 1964 opened the floodgates for women entering the labor market, especially in the nonprofit sector. ${ }^{19}$ The act required that employers give nondiscriminatory treatment to men and women in the areas of hiring, promotion, and other conditions of employment. The Civil Rights Act of 1964 and the Equal Pay Act of 1963 jump started a series of legislative efforts to standardize the equal treatment of men and women in the work force. ${ }^{20}$ Although women still have not gained equality with men, the women's movement of the late 1960s and beyond made women more aware of their opportunities and rights. ${ }^{21}$

The social change of the 1960s has led more women into the work force since that time. More women were searching for work and investing time and money into their own education and skills. $^{22}$

The percentage of women graduating from college steadily increased between 1961 and 1971. By 1981, 50 percent of college graduates were women. ${ }^{23}$ The number of women majoring

$$
\begin{aligned}
& { }^{17} \text { Ibid., } 3 . \\
& { }^{18} \text { Ibid., } 4 . \\
& { }^{19} \text { Ibid., } 39 . \\
& { }^{20} \text { Ibid., } 40 . \\
& { }^{21} \text { Ibid. } \\
& { }^{22} \text { Ibid. }
\end{aligned}
$$


in public relations grew at a rapid rate. According to Aldoory, nearly 80 percent of all public relations students were women in $1990 .{ }^{24}$ It seems that "society places a greater communication burden-opportunity on women, teaching them to listen and thus begin to understand communication’s most basic aspects." ${ }^{25}$ Many educators agree that "not only are most public relations students women, but also the best students are women. They communicate, observe, listen, and write better."26 By 1991, the occupational distributions and education levels of men and women entering the nonprofit sector were similar. ${ }^{27}$ The influx of women in the public relations profession met with a corresponding concern for diminished values and salaries in the field. $^{28}$

In Aldoory's 1998 research, she illuminated a growing concern of the feminization of the field of public relations due to the mass influx of women entering the profession. ${ }^{29}$ A three-part research report, published in 1986 by the IABC Research Foundation ${ }^{30}$ entitled The Velvet Ghetto, described the impact of the increasing numbers of women in the public relations profession. The report was based on three assumptions:

\footnotetext{
${ }^{23}$ Ibid.

${ }^{24}$ Linda Aldoory, “The Language of Leadership for Female Public Relations Professionals,” Journal of Public Relations Research 10, no. 2 (1998): 73.

${ }^{25}$ Tamara Gillis and Frank Wylie, “Two Views on 'Women in Public Relations: How Gender Influences Practice', Communication World 18, no. 4 (June/July 2001): 45.

${ }^{26}$ Ibid.

${ }^{27}$ Odendahl and O’Neill, “Women \& Power in the Nonprofit Sector,” 70.

${ }^{28}$ Aldoory, “The Language of Leadership for Female Public Relations Professionals,” 73.

${ }^{29}$ Ibid.

${ }^{30}$ Mission Statement of the IABC: “The IABC Research Foundation contributes to a body of knowledge that advances the practice, perception and effectiveness of communication. It serves IABC, its members and others in the profession through research on organizational communication.”
} 
(1) Women are more likely to perceive themselves as filling a technical rather than a managerial role;

(2) Women are paid substantially less than men, even when other variables are controlled; and

(3) When other professions have gone from male-dominated to female-dominated, those professions have all diminished in salary and status. ${ }^{31}$

The authors used in-depth interviews with senior-level public relations practitioners, six focus group interviews with practitioners held in the United States and Canada, and psychological testing of communication majors at eight universities to identify ideas and themes that might provide directions to a career field that seemed to be in the midst of gender transition. $^{32}$

In 1985, the gender majority in the public relations profession switched from male to female. In fact, the public relations industry continues to be female dominated. From 1985 to 1989, the male/female ratio of members in the IABC (International Association of Business Communicators) was a 40/60 ratio. In 1995, IABC membership was 70 percent female and in 2002, three out of four members, or 76 percent were women. ${ }^{33}$

According to the 2000 U.S. Department of Labor Statistics, the percentage of women to total workers in PR grew from 60 percent in 1985 to 68 percent in 1993, when it peaked. Since 1993, the percentage of women in the field has been declining at nearly half a percent every year.

\footnotetext{
${ }^{31}$ Carolyn Garrett Cline, Elizabeth Lance Toth, Judy VanSlyke Turk, Lynne Masel Walters, Nancy Johnson, and Hank Smith, The Velvet Ghetto: The Impact of the Increasing Percentage of Women in Public Relations and Business Communication, (San Francisco: IABC Foundation, 1986).

32 Elizabeth Lance Toth, "Making Peace with Gender Issues in Public Relations,” Public Relations Review 14, no. 3 (Fall 1988): 37.

${ }^{33}$ Heidi P. Taft, “Have Times Changed? IABC Research Foundation’s ‘The Velvet Ghetto’ Study Revisited,” Communication World 20, no. 2 (February/March 2003):
} 
This means that men have been entering the public relations profession at a faster rate since 1993. In essence, the ratio is slowly returning to equal. ${ }^{34}$

When The Velvet Ghetto was first published in 1985, it was thought that the rise of women in the public relations profession would lead to a salary decline. In 2000, the American Federation of Labor-Congress of Industrial Organizations reported that women were paid \$.73 for every dollar a man received, compared to the $\$ .726$ they received in $1985 .^{35}$ The good news is that women's salaries have not declined. However, the bad news is that after more than 15 years of fighting for gender equality, men still receive higher salaries than women in the public relations profession. ${ }^{36}$

For years, the term glass ceiling has been used to describe "the invisible barriers women face when dealing with salaries and promotion.”37 The public relations field is nearly 70 percent female. However, men are often favored for higher salaries and promotions to managerial positions. ${ }^{38}$ There is a significant salary gap between men and women in the public relations profession. On average, men’s salaries are 45 percent higher than women’s. In a 1995 study, the average man’s annual salary was $\$ 59,460$ compared to the $\$ 41,110$ a women with the same experience and credentials received. ${ }^{39}$ In 1998, a man’s average salary was \$72,000, \$16,000 higher than a woman’s average salary of $\$ 56,000 .^{40}$ In 1999 , Impulse Research for $P R$ Week

\footnotetext{
${ }^{34}$ Ibid.

${ }^{35}$ Ibid.

${ }^{36}$ Ibid.

${ }^{37}$ Linda Aldoory and Elizabeth Toth, “Gendered Profession: A Developing Theory for Public Relations,” Journal of Public Relations Research 14, no. 2 (2002): 103.

${ }^{38}$ Ibid.

${ }^{39}$ Ibid.
} 
reported that women earned 38 percent less than men. ${ }^{41}$ Finally, in 2000, the average salary for men was $\$ 81,920$ compared to the $\$ 59,026$ average salary for women. ${ }^{42}$

Dozier concedes in his 1988 research that there are a few reasons why women cannot break the glass ceiling, the first being gender stereotypes. Dozier defines gender stereotypes as "beliefs many people hold about typical characteristics of men (masculine stereotypes) and women (feminine stereotypes). ${ }^{43}$ He states that "boys and girls are rewarded for aspiring to characteristics deemed appropriate for members of their sex."44 Unfortunately for both women and public relations, the attributes for a good manager are masculine stereotypes. This makes it nearly impossible for women to break through the glass ceiling and participate in managerial decision making. ${ }^{45}$

Typically, women play the technician role in public relations where men play the managerial role. Dozier asserts that "the technician role is consistent with feminine stereotypes and consistent with common views about women's attachment to their work." ${ }^{\text {46 }}$ Furthermore, he states that "the managerial role requires attributes stereotypically associated with masculinity and with high levels of attachment to their work.",47

\footnotetext{
${ }^{40}$ Ibid.

${ }^{41}$ Ibid.

${ }^{42}$ Ibid.

${ }^{43}$ David M. Dozier, “Breaking Public Relations Glass Ceiling,” Public Relations Review 14, no. 3 (Fall 1998): 7.

${ }^{44}$ Ibid.

${ }^{45}$ Ibid.

${ }^{46}$ Ibid.

${ }^{47}$ Ibid.
} 
Finally, Dozier declares that "the segregation of women in the technician role serves as a powerful predictor of income differences between men and women practitioners and therefore, women makes less money than men of equal professional experience.»48

In the field of public relations, there are gender roles and values associated with men and women. In their 2000 research, Grunig, Toth, and Hon established a link between "feminine gender” and feminist values. These include “cooperation, respect, caring, nurturance, interconnection, justice, equality, honesty, sensitivity, perceptiveness, intuition, altruism, fairness, morality, and commitment."49 To understand this link between gender and values, central terms such gender and gender roles, sex and sex roles, and femininity and masculinity are defined.

The object of Grunig, Toth, and Hon’s research was to “explore gender, values, and public relations practice."50 They begin with the definition of "value.” Value is "an assessment of worth,"51 and therefore, the values people choose become important. It is generally agreed upon that “values develop from individuals’ cultural, biological, and genetic influences.”52 As a result, the exploration of his/her heritage - cultural, biological, and genetic - must occur to fully understand the values of men and women. ${ }^{53}$

The terms "gender" and "sex" are used in connection with feminist values when defining “gender.” These terms are often used interchangeably. There are many differing opinions on

\footnotetext{
${ }^{48}$ Ibid.

${ }^{49}$ Grunig, Toth, and Hon, “Feminist Values in Public Relations,” 1.

${ }^{50}$ Ibid., 2.

${ }^{51}$ M. Velasquez, Philosophy: A TutorialReader (Belmont, CA: Wadsworth, 1991).

${ }^{52}$ Grunig, Toth, and Hon, "Feminist Values in Public Relations," 2.

${ }^{53}$ Ibid.
} 
whether "gender" refers to the biological make-up or the social construction of a person, which at times causes confusion. Gender is a critically important term when referring to feminist values. Kohlberg theorized that "gender serves as an organizer whereby we develop a model for our own system of values and beliefs." ${ }^{54}$ In other words, "what we value depends largely on the reactions of the group with which we identify." 55 Bem, on the other hand, refers to "gender" as the "biological functions determined at birth: genitalia, body build, reproductive system, etc." 56 This led Powell to his theory that "gender is a scheme for categorizing people based on biological differences, and it, in turn, becomes a basis for assigning social differences”,57 (such as asking people to check "male" or "female" on a survey). ${ }^{58}$

There are universally accepted gender role differences between men and women.

Researchers cited such traits as "rationality, activeness, dominance, competitiveness, selfconfidence, aggressiveness, independence, boastfulness, and hostility” as describing men, and traits such as "empathy, dependence, passivity, sympathy, sensitivity, nurturance, shyness, and being high strung”59 as describing women. These traits are categorized into "agency and instrumentality” (a self-centered orientation concerned with achieving one’s end) for men's personality orientation and into "expressiveness and communication" (an others-centered orientation that seeks the good for all and characterized by cooperation) for women's. ${ }^{60}$

\footnotetext{
${ }^{54}$ L. Kohlberg, The Development of Sex Differences (Stanford, CA: Stanford University Press, 1966), 82-173.

${ }^{55}$ Grunig, Toth, and Hon, "Feminist Values in Public Relations," 2.

${ }^{56}$ S. L. Bem, Probing the Problem of Androgyny (Boston: Little, Brown, 1976), 48-62.

${ }^{57}$ G. N. Powell, Women and Men in Management (Newbury Park, CA: Sage, 1988).

${ }^{58}$ Grunig, Toth, and Hon, "Feminist Values in Public Relations,” 2.

${ }^{59}$ Youjin Choi and Linda Childers Hon, "The Influence of Gender Composition in Powerful Positions on Public Relations Practitioners' Gender-Related Perceptions,” Journal of Public Relations Research 14, no. 2 (2002): 233.
} 
However, these traits alone do not account for the gender inequality between men and women in social position or economic status. Bem did further research in 1993 and concluded that "social institutions (such as family and school) and societal culture make people believe that gender inequalities are a natural outcome of different biological traits. ${ }^{„ 61}$ Our society and culture places higher importance on male attributes than female attributes, which accounts for the higher social and economic status of men in our society.

In comparing with gender, "sex" involves such characteristics as "masculinity and femininity, which are characteristics that lead to social differences. ${ }^{\text {62 }}$ Certain traits tend to be associated with men and women, such as assertiveness and submissiveness. In essence, "sex is a matter of social rather than biological constructs." ${ }^{, 63}$

Sex roles are frequently described as feminine and masculine. According to Angrist, "sex role refers to the positions that men and women should occupy, the relationship between men and women, and the characteristics that distinguish them. These characteristics can describe behavior, personality, abilities, preferences, and values.”" ${ }^{\prime 4}$ Traditional sex roles for women have them cast as nurturers and caregivers. ${ }^{65}$

These traits led psychologists to suggest that women are more likely than men to possess characteristics, qualities, and values ideally suited for the field of public relations. ${ }^{66}$ Women

\footnotetext{
${ }^{60}$ Ibid.

${ }^{61}$ Ibid., 234.

${ }^{62}$ Grunig, Toth, and Hon, "Feminist Values in Public Relations,” 3.

${ }^{63}$ Ibid.

${ }^{64}$ S. A. Angrist, “The Study of Sex Roles,” Journal of Social Issues 15 (1969): 215-232.

${ }^{65}$ Grunig, Toth, and Hon, "Feminist Values in Public Relations,” 4.

${ }^{66}$ Ibid., 2.
} 
practice a two-way communication model of public relations, which involves "an equal concern for the organization's clients as well as the organization itself."67

Consequently, the terms "femininity" and "masculinity" will be discussed as a means to further clarify the perceptions of men and women in our culture. According to Spence and Helmreich, femininity and masculinity are defined as "attributes and behaviors that distinguish normatively between the sexes in a given society."68 In essence, "femininity” and masculinity” are what society expects and may not be necessarily what a person prefers. Not every man acts completely “masculine” as not every woman acts totally “feminine.” A man can possess feminine traits and a female can possess masculine traits. "Masculinity" and "femininity" are stereotypes in our culture in that men are considered, as Grunig, Toth, and Hon state, “powerful and dominant” while women are considered "subordinate to men."69 What is not fully known, is whether these stereotypes are unjustly applied to men and women in our culture. Do women take on the role as caregivers and nurturers because that is what society expects or is it because women value those roles? ${ }^{70}$ This subject is continually being researched.

Finally the author shall define the term "feminist," as the field of public relations is said to be rooted in "feminist” values. In their 1985 book, Kramarae and Treichler define "feminist” as “a person, female or male, whose worldview places the female in the center of life and society, and/or who is not prejudiced based on gender or sexual preferences. Also, anyone in a male dominated or patriarchal society who works toward the political, economic, spiritual,

\footnotetext{
${ }^{67}$ Ibid., 3.

${ }^{68}$ J. T. Spence and R. L. Helmreich, "Masculine Instrumentality and Feminine Expressiveness: Their Relationship with Separate Role Attributes and Behaviors," Psychology of Women Quarterly 5 (1980): 147.

${ }^{69}$ Grunig, Toth, and Hon, "Feminist Values in Public Relations," 4.

${ }^{70}$ Ibid.
} 
sexual, and social equality of women."71 ${ }^{71}$ This leads us to the fact that the field of public relations is a highly intuitive business based on relationships, whether the relationship is with the public, a client, the media, or even fellow co-workers. Based on the gender stereotypes in our society, women are believed to be more adept in dealing with relationships. They possess feminist values, such as "respect, caring, honesty, sensitivity, interconnection, and self-determination,"72 to name a few. There are more feminist values worth mentioning as many are included in the introductory chapter of the book Excellence in Public Relations and Communication Management $^{73}$ : “altruism, commitment, equality, ethics, fairness, forgiveness, integrity, justice, loyalty, morality, nurturance, perfection, quality of life, standards, tolerance, and cherishing children., ${ }^{74}$

Grunig, Toth, and Hon state that "some scholars have suggested that the most effective public relations grows out of an entire world view that is feminine." ${ }^{, 75}$ It is said that feminist values in public relations have both intrinsic and extrinsic values. ${ }^{76}$ Intrinsic values are values that are worthwhile in itself, and extrinsic values are "a means to something else."77 Grunig, Toth and Hon use an example of honesty. Honesty is an attribute in itself. In public relations, being honest with the public leads to trust, which enhances the relationship between the

\footnotetext{
${ }^{71}$ C. Kramarae and P.A. Treichler, A Feminist Dictionary (London: Pandora, 1985).

${ }^{72}$ Grunig, Toth, and Hon, "Feminist Values in Public Relations,” 6.

${ }^{73}$ J. E. Grunig, Excellence in Public Relations and Communication Management (Hillsdale, NJ: Lawrence Erlbaum Associates, Inc., 1992): 1-28.

${ }^{74}$ Grunig, Toth, and Hon, "Feminist Values in Public Relations,” 6.

${ }^{75}$ Ibid., 7.

${ }^{76}$ Ibid., 8.

${ }^{77}$ Ibid.
} 
organization and the public. ${ }^{78}$ If women are more likely than men to possess these aforementioned values, a question arises as to whether a woman or a man is better suited for executive and managerial positions in the public relations profession.

There is considerable debate in management and feminist literature as to whether there are gender-based differences in management styles in public relations. ${ }^{79}$ Researchers have argued that "women are perceived as inappropriate for management roles because the normative managerial image is constructed on a stereotype that traditionally favors male traits such as aggression, dominance, and competitiveness.." ${ }^{, 0}$ Female traits such as “dependence, emotionality, and passivity are seen as negative and unsuited for management.”81

In the 1985 "Velvet Ghetto" study, the researchers found that "organizations did not perceive women as good managers, and therefore tended to place women in tactician verses managerial roles." ${ }^{82}$ One reason was because "women found it easier to balance home and work life when they had less responsibility at the office. ${ }^{83}$ This leads to the theory that women juggle three careers of work, marriage, and parenting. ${ }^{84}$

Researchers have studied the traits of females who reached managerial positions. They have discovered that "female public relations managers, particularly in the 1970s and 1980s, tried to demonstrate that they were not different from male managers in management style and in

\footnotetext{
${ }^{78}$ Ibid.

${ }^{79}$ Odendahl and O'Neill, Women \& Power in the Nonprofit Sector, 12.

${ }^{80}$ Choi and Hon, “The Influence of Gender Composition in Powerful Positions on Public Relations Practitioners' Gender-Related Perceptions,” 234.

${ }^{81}$ Ibid.

${ }^{82}$ Taff, “Times Have Changed? IABC Research Foundation’s ‘The Velvet Ghetto” Study Revisited,” 10.

${ }^{83}$ Ibid.
} 
doing so suppressed female traits. ${ }^{85}$ When women took over traditionally male positions, they felt the need to suppress their feminine traits and display more of the stereotypical masculine traits to be respected. In other words, women mirrored their male manager counterparts because it was believed that men's traits were required for successful management. ${ }^{86}$

In 1989, researchers found that men still believed masculine traits were the key to successful public relations management, while women changed their perceptions. Women now believed that for a manager to be successful, he/she had to possess both masculine as well as feminine traits. ${ }^{87}$

As more women entered the nonprofit public relations workforce, they began to embrace their feminine qualities and utilize them for the betterment of the sector. Although they continue to struggle for managerial positions, they are finding it more accepting of female leadership.

Female participation is especially prominent in the nonprofit sector. Odendahl and O’Neill define the nonprofit sector as "incorporated nongovernmental organizations granted tax exempt status by the Internal Revenue Service and usually state agencies. These include both charitable, or public benefit organizations, environmental or other advocacy efforts and 'mutual benefit’ nonprofits such as fraternal organizations, social clubs, political parties, and professional associations. ${ }^{, 88}$ The American nonprofit sector includes about 1.4 million organizations. ${ }^{89}$

\footnotetext{
${ }^{84}$ Gills and Wylie, “Two Views on 'Women in Public Relations: How Gender Influences Practice’,” 45.

${ }^{85}$ Choi and Hon, "The Influence of Gender Composition in Powerful Positions on Public Relations Practitioners' Gender-Related Perceptions,” 235.

${ }^{86}$ Ibid.

${ }^{87}$ Ibid.

${ }^{88}$ Odendahl and O’Neill, Women \& Power in the Nonprofit Sector, 2-3.

${ }^{89}$ Ibid., 3.
} 
As Odendahl and O’Neill state, the nonprofit sector is gendered in that the overwhelming majority of its workers are female. Many tasks performed in nonprofit settings are economically devalued in society because the skills the jobs require are taken for granted and treated as invisible. This is the result of the fact that the work is often performed by women and that the skills and talents required of service workers are often assumed to be natural abilities of women, and therefore deserve no special compensation. ${ }^{90}$ The values used to describe the nonprofit sector - "voluntarism, pluralism, altruism" - are also associated with the feminine. So is a concern with “charity, service, and good works.”91

The 1970s and 1980s brought important and generally positive changes for women in the nonprofit sector. Opportunities for women in the nonprofit sector increased after the Civil Rights Act was passed in $1964 .^{92}$ Not only did more professional women find employment in the nonprofit sector, but the percentage of nonprofit women in management jobs more than tripled as well. ${ }^{93}$

Women appear to be having a relatively easier time moving into positions of leadership in nonprofit organizations than for-profit organizations. ${ }^{94}$ In certain respects, "women are breaking down barriers as they enter historically male professions and nonprofit managerial positions."95 It is easier for women to enter managerial jobs in organizations in which a large number of women already work. So, given the large numbers of women who already work in

\footnotetext{
${ }^{90}$ Ibid., 79-80.

${ }^{91}$ Ibid

${ }^{92}$ Ibid., 70

${ }^{93}$ Ibid., 95.

${ }^{94}$ Ibid.

${ }^{95}$ Ibid.
} 
the nonprofit sector, it is easier for women to enter into these organizations. This explanation ties in with Barbara Bergmann’s “segregation code.” Based on her investigation of several corporations, Bergmann "noted a pattern consistent with a taboo on women supervising men. Thus, it is easier for women to enter professional and managerial jobs in sectors in which they predominately supervise women." ${ }^{96}$

While wages of men and women in the nonprofit sector are approximately equal, wages of managerial women are more than 20 percent below wages of managerial men. ${ }^{97}$ As Odendahl and O’Neill note, “women managers are more likely than men to practice participative, consensus-oriented decision making, and understand and value the personal interests of workers."98

Women are much more likely to head the largest nonprofit organizations than they are to head the largest for-profit or government organizations. In 1992, sixteen of the nation’s one hundred largest nonprofits had chief executive officers who were women, whereas only one Fortune 500 corporation was headed by a woman. ${ }^{99}$

Women held only about 35 percent of nonprofit managerial positions in 1970, as compared with 58 percent in 1990. While this does not mean there is equality at all levels of management, it does make clear that women in the nonprofit sector now hold a much higher percentage of the positions commonly associated with organizational power than was the case two decades ago. ${ }^{100}$

\footnotetext{
${ }^{96}$ Ibid.

${ }^{97}$ Ibid., 42.

${ }^{98}$ Ibid., 12.

${ }^{99}$ Ibid., 6.
} 
In essence, the exclusion of women in the economic arena has shaped feminist theory into a broad, multi-faceted spectrum. Trivialization of the work and roles of women has been a major theme in feminist literature. ${ }^{101}$ As stated earlier, "Feminist theory points simultaneously to the way in which the exclusion of women has shaped professional practices and to the effects within the knowledge of each discipline of socially and historically constructed gender identities. $^{\text {,102 }}$

Feminist theorists examine the way women are viewed in our society. They decenter the norm, recognizing that the "women on the margins have, in fact, defined the center."103 They aim to demonstrate the way that gender works to legitimize the structure of power. ${ }^{104}$

The most important change in feminist theory is the rising expectations of women themselves. The general issue of women's power in American society must include serious attention to the effect of women's work in the nonprofit sector. ${ }^{105}$ Historically, the nonprofit sector is a mechanism for dramatic reallocation of power and opportunity in American society. ${ }^{106}$ It is highly likely that such broad social and economic changes affect the relative power and status of women in the nonprofit sector. ${ }^{107}$

Women fought for and won liberation and some measure of economic independence by using nonprofit organizations to bring pressure on the government and corporate

\footnotetext{
${ }^{100}$ Ibid., 13.

${ }^{101}$ Odendahl and O’Neill, Women and Power in the Nonprofit Sector,” 13.

102 Shapiro, “Introduction: History and Feminist Theory, or Talking Back to the Beadle,” 1.

103 Ibid.

104 Ibid.

${ }^{105}$ Odendahl and O’Neill, Women \& Power in the Nonprofit Sector, 11.

${ }^{106}$ Ibid..
} 
organizations. ${ }^{108}$ However, the feminization of some occupations has led to their devaluation, and conversely the increase in prestige of some nonprofit efforts- social welfare, health, culture and education. ${ }^{109}$ As public relations is now considered gendered female, the devaluation of the profession is constantly being studied by researchers throughout our society.

In view of the remarkable political and social accomplishments of such women as Dorothea Dix and Clara Barton in the nonprofit sector more than a century ago, it is ironic that “power” in American society is still categorized in mostly masculine terms and surrounded by male images. $^{110}$

Since women have an easier time entering the nonprofit sector because it is considered gendered female, and it is easier for women to enter professional and managerial jobs in sectors in which they predominately supervise women, this study focuses on the rise of female managerial positions in both nonprofit public relations and corporate public relations based on masculine and feminist values.

\section{HYPOTHESES}

H1: Women who place greater value on feminist traits are more likely to obtain management positions in the nonprofit sector.

H2: Women who place greater value on masculine traits are more likely to obtain management positions in the corporate sector.

\footnotetext{
${ }^{107}$ Ibid., 9.

${ }^{108}$ Ibid., 11.

109 Ibid., 14.

${ }^{110}$ Ibid., 11.
} 


\section{METHODOLOGY}

For the purpose of this study, the author conducted a survey of female public relations practitioners in the Public Relations Society of America. Since survey research reaches larger populations, it assists researchers in developing a more representative picture of the selected population. According to Babbie, "survey research is probably the best method available...for a population too large to observe directly."111

The influence of masculine and feminist values on managerial positions in public relations was measured by developing a questionnaire for use in the study. The unit of analysis was female executives in the public relations profession and the unit of observation was the women’s responses to a survey containing 12 descriptive adjectives regarding masculine and feminine gender-related traits gathered from the literature reviewed and 13 additional statements regarding female management in the public relations sector.

A total of 40 traits were gathered from the literature reviewed and were narrowed down to 12 by the researcher. The following 12 adjectives have been used extensively as reliable and valid for defining perceived masculinity and femininity and are defined by The American Heritage Dictionary, $4^{\text {th }}$ Edition $^{112}$ :

1. Communal: Of or relating to the public or community.

2. Cooperative: The ability to work together for a common end; willing to cooperate.

3. Interconnected: The ability to connect or be connected with each other or a group.

4. Perceptive: 1. Of or relating to perception. 2a. Having the ability to perceive.

2b. Marked by discernment; insightful.

\footnotetext{
${ }^{111}$ E.R. Babbie, The Practice of Social Research, $9^{\text {th }}$ Edition, (Belmont, CA: Wadsworth/Thompson Learning, 2000), 238.

112 “The American Heritage Dictionary,” $4^{\text {th }}$ ed. (New York, NY: Dell Publishing/Random House, 2001).
} 
5. Sensitive: 1. Capable of perceiving. 2. Responsive to external conditions.

3. Susceptible to the attitudes, feelings, or circumstances of others.

4. Registering very slight differences or changes.

6. Understanding: $\mathbf{1}$. The quality of discernment; comprehension. 2. Compassionate; Sympathetic.

7. Aggressive: 1. Inclined to hostile behavior. 2. Bold and enterprising. 3. Intense or harsh.

8. Assertive: The ability to put (oneself) forward boldly or forcefully.

9. Competitive: One who participates in the act of competing with others.

10. Dominant: 1. Exercising the most influence or control. 2. Most prominent, as in position.

11. Independent: $\mathbf{1}$. Not governed by a foreign power. 2. Free from the influence, guidance, or control of others.

12. Self-Reliant: Having or exhibiting trust in or dependence on oneself.

The latter six adjectives are considered masculine traits while the former six adjectives are considered feminine traits. The 13 final survey statements regarding female management in public relations stem from research gained throughout the literature reviewed.

A purposive and systematic sampling technique was used to pinpoint female public relations practitioners who have joined PRSA and whose title reflected an executive or managerial position (i.e. Director, Executive Vice President, Vice President, Chief Executive Officer, Principal). The researcher used the PRSA’s 2004 membership guide, The Blue Book, which lists nearly 20,000 public relations specialists, to select the research sample. The executives who made up the dataset were determined through the method of random sampling 
without replacement. Wimmer and Dominick defined a random sample as “a subgroup or subset of a population selected in such a way that each unit has an equal chance of being selected.”113 Following this method, the researcher picked 812 female executives from corporate, nonprofit and agency settings to be surveyed. The original dataset had over 1620 names, which the researcher deemed too large to survey. Alternating names were chosen, leaving 812 female executives to be surveyed. The researcher included women who work in an agency setting because a majority of women work for agencies that have both nonprofit and corporate clients. To exclude women who work in agencies would leave-out a majority of female executives in the public relations profession.

The questionnaire contained three sections. The 12 feminine/masculine traits appeared in the first two sections and the 13 additional statements appeared in the final section. On the first two lists, the respondents were asked how much each trait is characteristic of men and women on a Likert scale ranging from 1 “strongly agree” to 4 “strongly disagree.” This was done to ascertain whether the respondents believe certain traits are either masculine or feminine. It tested the consistency of the measuring instruments. In the final section of statements, the respondents were asked how much these statements apply to themselves and their roles as public relations executives. Again, a Likert scale ranging from 1 “strongly agree” to 4 "strongly disagree” was used.

The questionnaire was administered via email rather than through the traditional mail system because of its lower cost. Internet technology provides immediate results and a more convenient mode of research. Also, email is a common tool used by all public relations practitioners.

\footnotetext{
${ }^{113}$ Roger D. Wimmer and Joseph R. Dominick, "Mass Media Research,” $7^{\text {th }}$ ed. (Belmont, CA: Wadsworth/Thomas Learning, 2003), 88-89, 465.
} 
The surveys were mass-emailed "BCC (Blind Carbon Copy)" to keep the identities of the respondents confidential. They were sent to the 812 female public relations executives on a rolling basis on Tuesday, March 1, Wednesday, March 2, and Thursday, March 3, 2005. A follow-up email reminder was sent to those who did not respond initially on Thursday, March 10, 2005. The respondents were given until Friday, March 20, 2005 to complete the questionnaire.

\section{RESULTS AND DISCUSSION}

Of the 812 surveys, 198 were sent to women who work in a nonprofit setting, 287 were sent to women who work in the corporate sector, and 327 were sent to women working for a public relations agency. By March 20, 2005, 121 surveys were answered and returned to the researcher.

Before discussing the hypotheses, it is important to note the demographics of the female executives in the dataset. A majority of the respondents have worked in public relations over 16 years (see Table 1.1) and have an annual salary above \$86,000 (see Table 1.2). Of the 121 surveys collected, the majority of respondents are from an agency setting (see Table 1.3). With only nine respondents from the nonprofit setting, valid conclusions about female executives in the nonprofit sector cannot be obtained.

Table 1.1

\begin{tabular}{|c|c|}
\hline Years Worked in PR & Percent of Respondents \\
\hline $1-5$ Years & $1.7 \%$ \\
\hline $6-10$ Years & $14.0 \%$ \\
\hline $11-15$ Years & $17.4 \%$ \\
\hline $16-20$ Years & $23.1 \%$ \\
\hline $21-25$ Years & $24.8 \%$ \\
\hline $26-30$ Years & $7.4 \%$ \\
\hline $31+$ Years & $11.6 \%$ \\
\hline
\end{tabular}


Table 1.2

\begin{tabular}{|c|c|}
\hline Annual Salary & Percent of Respondents \\
\hline$\$ 16,000-\$ 25,000$ & $.9 \%$ \\
\hline$\$ 36,000-\$ 45,000$ & $1.7 \%$ \\
\hline$\$ 46,000-\$ 55,000$ & $7.7 \%$ \\
\hline$\$ 56,000-\$ 65,000$ & $7.7 \%$ \\
\hline$\$ 66,000-\$ 75,000$ & $18.8 \%$ \\
\hline$\$ 76,000-\$ 85,000$ & $12.8 \%$ \\
\hline$\$ 86,000-\$ 95,000$ & $16.2 \%$ \\
\hline$\$ 96,000+$ & $34.2 \%$ \\
\hline
\end{tabular}

Table 1.3

\begin{tabular}{|c|c|c|}
\hline Sector & $\begin{array}{c}\text { Number of } \\
\text { Respondents }\end{array}$ & $\begin{array}{c}\text { Percent of } \\
\text { Respondents }\end{array}$ \\
\hline Nonprofit & 9 & $7.5 \%$ \\
\hline Corporate & 42 & $35.0 \%$ \\
\hline Agency & 69 & $57.5 \%$ \\
\hline
\end{tabular}

In the first section of the survey, the women were asked how much each attribute (aggressive, assertive, communal, competitive, cooperative, dominant, independent, interconnected, perceptive, self-reliant, sensitive, and understanding) is characteristic of men on a Likert scale ranging from 1 "strongly agree” to 4 "strongly disagree.” Next, they were asked how much each attribute is characteristic of women. Out of the six traits used extensively as reliable and valid for defining perceived masculinity (aggressive, assertive, competitive, dominant, independent, and self-reliant), the majority of respondents "strongly agree" or "agree" that each attribute is characteristic of men (see Tables 2.1, 2.2, 2.3, 2.4, 2.5 and 2.6). Remarkably, 100 percent of the respondents either "strongly agree” or "agree" that men are competitive (see Table 2.3) compared to 84.3 percent who "strongly agree” or "agree” that women are competitive. 
Table 2.1

AGGRESSIVE

\begin{tabular}{|c|c|c|}
\hline & Men & Women \\
\hline Strongly Agree & $36.0 \%$ & $4.3 \%$ \\
\hline Agree & $58.8 \%$ & $47.0 \%$ \\
\hline Disagree & $4.4 \%$ & $46.1 \%$ \\
\hline Strongly Disagree & $.9 \%$ & $2.6 \%$ \\
\hline
\end{tabular}

Table 2.2

ASSERTIVE

\begin{tabular}{|c|c|c|}
\hline & Men & Women \\
\hline Strongly Agree & $24.3 \%$ & $4.3 \%$ \\
\hline Agree & $69.6 \%$ & $76.5 \%$ \\
\hline Disagree & $5.2 \%$ & $18.3 \%$ \\
\hline Strongly Disagree & $.9 \%$ & $.9 \%$ \\
\hline
\end{tabular}

Table 2.3

COMPETITIVE

\begin{tabular}{|c|c|c|}
\hline & Men & Women \\
\hline Strongly Agree & $49.6 \%$ & $10.4 \%$ \\
\hline Agree & $50.4 \%$ & $73.9 \%$ \\
\hline Disagree & $0 \%$ & $15.7 \%$ \\
\hline Strongly Disagree & $0 \%$ & $0 \%$ \\
\hline
\end{tabular}

Table 2.4

DOMINANT

\begin{tabular}{|c|c|c|}
\hline \multicolumn{2}{|c|}{ Men } & Women \\
\hline Strongly Agree & $24.3 \%$ & $1.7 \%$ \\
\hline Agree & $68.7 \%$ & $46.1 \%$ \\
\hline Disagree & $7.0 \%$ & $50.4 \%$ \\
\hline Strongly Disagree & $0 \%$ & $1.7 \%$ \\
\hline
\end{tabular}


Table 2.5

INDEPENDENT

\begin{tabular}{|c|c|c|}
\hline & Men & Women \\
\hline Strongly Agree & $26.1 \%$ & $7.0 \%$ \\
\hline Agree & $57.4 \%$ & $75.7 \%$ \\
\hline Disagree & $15.7 \%$ & $17.4 \%$ \\
\hline Strongly Disagree & $.9 \%$ & $0 \%$ \\
\hline
\end{tabular}

Table 2.6

SELF-RELIANT

\begin{tabular}{|c|c|c|}
\hline \multicolumn{2}{|c|}{ Men } & Women \\
\hline Strongly Agree & $7.8 \%$ & $14.8 \%$ \\
\hline Agree & $73.9 \%$ & $67.8 \%$ \\
\hline Disagree & $17.4 \%$ & $17.4 \%$ \\
\hline Strongly Disagree & $.9 \%$ & $0 \%$ \\
\hline
\end{tabular}

With the exception of "aggressive” and "dominant” (where the agree/disagree margin is extremely close- see Tables 2.1 and 2.4) the respondents overwhelmingly believe the masculine traits also pertain to women. The only trait the majority of the respondents either "strongly disagree” or "disagree” as pertaining to women is “dominant,” with 52.1 percent (see Table 2.4). Essentially, the masculine traits are not only characteristics of men, they are also characteristics of women. Concerning the "self-reliant" trait, the respondents showe they believe women are slightly more self-reliant than men (see Table 2.6).

Out of the six traits used extensively as reliable and valid for defining perceived femininity (communal, cooperative, interconnected, perceptive, sensitive, and understanding), the respondents overwhelmingly "strongly agree" or "agree" that each trait is characteristic of women (see Tables 3.1, 3.2, 3.3, 3.4, 3.5, and 3.6). The respondents marked no "strongly disagree” pertaining to any feminine trait. 
Table 3.1

COMMUNAL

\begin{tabular}{|c|c|c|}
\hline \multicolumn{2}{|c|}{ Men } & Women \\
\hline Strongly Agree & $2.6 \%$ & $17.4 \%$ \\
\hline Agree & $21.1 \%$ & $79.1 \%$ \\
\hline Disagree & $70.2 \%$ & $3.5 \%$ \\
\hline Strongly Disagree & $6.1 \%$ & $0 \%$ \\
\hline
\end{tabular}

Table 3.2

COOPERATIVE

\begin{tabular}{|c|c|c|}
\hline \multicolumn{2}{|c|}{ Men } & Women \\
\hline Strongly Agree & $1.7 \%$ & $16.5 \%$ \\
\hline Agree & $78.4 \%$ & $77.4 \%$ \\
\hline Disagree & $21.7 \%$ & $6.1 \%$ \\
\hline Strongly Disagree & $1.7 \%$ & $0 \%$ \\
\hline
\end{tabular}

Table 3.3

INTERCONNECTED

\begin{tabular}{|c|c|c|}
\hline & Men & Women \\
\hline Strongly Agree & $7.0 \%$ & $14.9 \%$ \\
\hline Agree & $41.2 \%$ & $78.9 \%$ \\
\hline Disagree & $47.4 \%$ & $6.1 \%$ \\
\hline Strongly Disagree & $4.4 \%$ & $0 \%$ \\
\hline
\end{tabular}

Table 3.4

PERCEPTIVE

\begin{tabular}{|c|c|c|}
\hline \multicolumn{2}{c}{ Men } & Women \\
\hline Strongly Agree & $1.8 \%$ & $40.0 \%$ \\
\hline Agree & $28.1 \%$ & $57.4 \%$ \\
\hline Disagree & $64.9 \%$ & $2.6 \%$ \\
\hline Strongly Disagree & $5.3 \%$ & $0 \%$ \\
\hline
\end{tabular}


Table 3.5

SENSITIVE

\begin{tabular}{|c|c|c|}
\hline \multicolumn{2}{|c|}{ Men } & Women \\
\hline Strongly Agree & $.9 \%$ & $24.3 \%$ \\
\hline Agree & $27.2 \%$ & $73.0 \%$ \\
\hline Disagree & $64.0 \%$ & $2.6 \%$ \\
\hline Strongly Disagree & $7.9 \%$ & $0 \%$ \\
\hline
\end{tabular}

Table 3.6

UNDERSTANDING

\begin{tabular}{|c|c|c|}
\hline \multicolumn{2}{|c|}{ Men } & Women \\
\hline Strongly Agree & $1.7 \%$ & $25.4 \%$ \\
\hline Agree & $45.2 \%$ & $67.5 \%$ \\
\hline Disagree & $47.8 \%$ & $7.0 \%$ \\
\hline Strongly Disagree & $4.3 \%$ & $0 \%$ \\
\hline
\end{tabular}

While the respondents overwhelmingly "strongly agree” or "agree” the aforementioned traits are characteristic of women, they also believe men are nearly as cooperative as women (see Table 3.2). While they agree men are neither communal (see Table 3.1), perceptive (see Table 3.4), nor sensitive (see Table 3.5), they are decidedly divided on whether men are interconnected (see Table 3.3) and understanding (see Table 3.6).

Overall, the respondents believe women are aggressive, assertive, competitive, independent, self-reliant, communal, cooperative, interconnected, perceptive, sensitive, and understanding. Men are aggressive, assertive, competitive, dominant, independent, self-reliant, and cooperative. Essentially, the respondents believe each trait, with the exception of “dominant," is characteristic of women. On the other hand, the respondents believe each masculine trait is characteristic of men and only one feminine trait, "cooperative," is also characteristic of men. 
Hypothesis 1, women who place greater value on feminist traits are more likely to obtain management positions in the nonprofit sector, is rejected. Although 67.2 percent of the respondents believe women have a relatively easier time elevating to positions of leadership in nonprofit organizations than corporate organizations (see Table 4.1) and slightly more than half believe it is easier for women to enter executive and managerial jobs in sectors in which they predominately supervise women (see Table 4.2), 63.6 percent of respondents "strongly disagree” or "disagree” that women who are sensitive, honest, and tolerant (feminist values) are more likely to become executives in the nonprofit sector (see Table 4.3). Thus, hypothesis 1 is rejected.

Table 4.1

Women have a relatively easier time elevating to positions of leadership in nonprofit organizations than corporate organization.

\begin{tabular}{|c|c|}
\hline & Valid Percent \\
\hline Strongly Agree & $13.8 \%$ \\
\hline Agree & $53.4 \%$ \\
\hline Disagree & $28.4 \%$ \\
\hline Strongly Disagree & $4.3 \%$ \\
\hline
\end{tabular}

Table 4.2

It is easier for women to enter executive and managerial jobs in sectors in which they predominately supervise women.

\begin{tabular}{|c|c|}
\hline & Valid Percent \\
\hline Strongly Agree & $4.2 \%$ \\
\hline Agree & $50.4 \%$ \\
\hline Disagree & $39.5 \%$ \\
\hline Strongly Disagree & $5.9 \%$ \\
\hline
\end{tabular}




\section{Table 4.3}

$\begin{aligned} & \text { Women who are sensitive, honest and tolerant (feminine values) } \\
& \text { are more likely to become executives in the nonprofit sector. } \\
& \text { Valid Percent }\end{aligned}$
\begin{tabular}{|c|c|}
\hline Strongly Agree & $4.2 \%$ \\
\hline Agree & $32.2 \%$ \\
\hline Disagree & $56.8 \%$ \\
\hline Strongly Disagree & $6.8 \%$ \\
\hline
\end{tabular}

Hypothesis 2, women who place greater value on masculine traits are more likely to obtain management positions in the corporate sector, is accepted. 53.7 percent of the respondents "strongly agree” or agree” that the attributes of a good public relations executive are self-reliant, aggressive, and independent (masculine traits) (see Table 5.1).

Table 5.1

The attributes of a good public relations executive are self-reliant, aggressive, and independent.

\begin{tabular}{|c|c|}
\hline & Valid Percent \\
\hline Strongly Agree & $27.3 \%$ \\
\hline Agree & $26.4 \%$ \\
\hline Disagree & $43.0 \%$ \\
\hline Strongly Disagree & $3.3 \%$ \\
\hline
\end{tabular}

When asked if our society places higher importance on male attributes than female attributes, 68.9 percent of the respondents either "strongly agree” or "agree” (see Table 5.2). 59.8 percent of the respondents either "strongly agree” or "agree” that the higher social and economic status of men in our society is a result of society placing higher importance on male attributes than female attributes (see Table 5.3). 


\section{Table 5.2}

Our society and culture places higher importance on male attributes than female attributes.

\begin{tabular}{|c|c|}
\hline & Valid Percent \\
\hline Strongly Agree & $19.3 \%$ \\
\hline Agree & $49.6 \%$ \\
\hline Disagree & $22.7 \%$ \\
\hline Strongly Disagree & $8.4 \%$ \\
\hline
\end{tabular}

Table 5.3

The higher social and economic status of men in our society is a result of society placing higher importance on male attributes than female attributes.

\begin{tabular}{|c|c|}
\hline & Valid Percent \\
\hline Strongly Agree & $19.7 \%$ \\
\hline Agree & $40.2 \%$ \\
\hline Disagree & $31.6 \%$ \\
\hline Strongly Disagree & $8.5 \%$ \\
\hline
\end{tabular}

When asked if they feel more respected when being assertive, dominant, and self-

confident (masculine values) while performing managerial tasks, 58.6 percent of the respondents either "strongly agree” or “agree” (see Table 5.4).

\section{Table 5.4}

I feel more respected when I am assertive, dominant, and self-confident while performing managerial tasks.

\begin{tabular}{|c|c|}
\hline & Valid Percent \\
\hline Strongly Agree & $15.5 \%$ \\
\hline Agree & $43.1 \%$ \\
\hline Disagree & $38.8 \%$ \\
\hline Strongly Disagree & $2.6 \%$ \\
\hline
\end{tabular}


Finally, 70 percent of the respondents either "strongly agree” or "agree” that women who are aggressive, dominant, and competitive (masculine values) are more likely to become executives in the corporate sector (see Table 5.5). Thus, hypothesis 2 is accepted.

\section{Table 5.5}

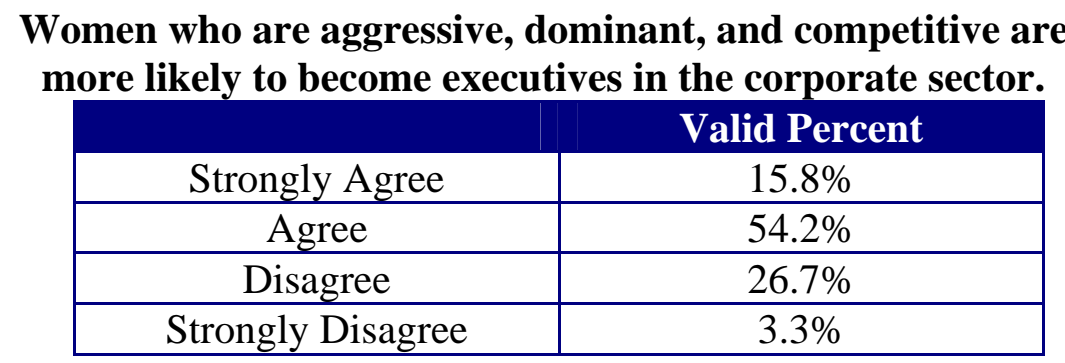

While the respondents disagree that women who exude more feminine traits are more likely to obtain management positions in the nonprofit public relations sector, they agree that women who exude more masculine traits are more likely to obtain management positions in the corporate public relations sector. When asked if women must display more masculine qualities to be a successful public relations executive, 70.8 percent of the respondents "strongly disagree” or "disagree” (see Table 6.1). Concurrently, when asked if women must suppress their feminine traits to be successful public relations executives, an overwhelming 93.3 percent of respondents either "strongly disagree” or “disagree” (see Table 6.2). In essence, the respondents agree women must not be overtly feminine or overtly masculine to be successful public relations practitioners.

Table 6.1

To be a successful public relations executive, women must display more masculine qualities.

\begin{tabular}{|c|c|}
\hline & Valid Percent \\
\hline Strongly Agree & $2.5 \%$ \\
\hline Agree & $26.7 \%$ \\
\hline Disagree & $45.0 \%$ \\
\hline Strongly Disagree & $25.8 \%$ \\
\hline
\end{tabular}




\section{Table 6.2}

To be a successful public relations executive, women must suppress their feminine traits.

\begin{tabular}{|c|c|}
\hline & Valid Percent \\
\hline Strongly Agree & $1.7 \%$ \\
\hline Agree & $5.0 \%$ \\
\hline Disagree & $58.8 \%$ \\
\hline Strongly Disagree & $34.5 \%$ \\
\hline
\end{tabular}

The researcher included a "Comments/Concerns" section at the end of the questionnaire, giving the respondents the opportunity to add additional information. Although most comments wished the researcher “Good Luck” with her research, nearly 30 respondents added their views on leadership in public relations. The majority of women agree that true leaders stand out whether they are male or female. As one woman responded, "Being a public relations practitioner requires you to be a chameleon, and to quickly adapt to new situations. Sometimes it pays to be more 'female' and other times, to be more 'male'.”

Similarly, the respondents agree the masculine/feminine traits are not attributable to gender, but to the individual. While there are some "feminine-like" qualities common to women and vice versa men, a person’s attributes are more individually driven. One respondent commented, "Different traits work better in different situations. Those who properly fit their attributes to what they do are more successful. Within PR, there are many different opportunities to properly use the attributes you have to achieve success.”

Essentially, to be a good public relations executive, whether in the nonprofit or corporate sector, one must embrace and utilize both masculine and feminine qualities. It is interesting that the respondents believe 11 out of the 12 aforementioned traits are characteristics of women, with the exception of dominant, a universally accepted male trait. Conversely, they believe only one 
feminine trait is characteristic of men, cooperative. Essentially, women perceive men as not having feminist values. Future research can examine executive men in public relations to see if they respond in the same manner, meaning both masculine and feminine traits are characteristic of men, while the feminine traits are solely characteristic of women.

\section{CONCLUSION}

The purpose of this study was to examine female public relations executives and their roles in management positions in both the corporate and nonprofit sectors based on masculine and feminist values. The researcher concludes that while women have a relatively easier time elevating to positions of leadership in sectors in which they predominately supervise women, namely the nonprofit sector, they do not gain these positions based solely on feminist values. Conversely, women who exude more masculine traits are more likely to elevate to positions of leadership in the corporate sector.

The researcher was surprised by many of the harsh responses from female executives who refused to participate in the survey. One executive wrote, "Men are men. Women are women. Get over it. And stop using the term “female.” I am a woman. This is not biology class." Another respondent commented, "I do not have time to fill-out a silly feminist graduate student survey.” The researcher concluded the questionnaire struck a nerve in some female executives. After exchanging numerous emails with one of the participants who had a question regarding the survey, the researcher remarked on the harsh responses received. Although her identity must be kept confidential, the participant explained the responses and sparked an idea for future research. This is her response: "What is not covered here are other factors such as 1) Do you have children? 2) Have you ever been married? 3) How many times have you been married? 4) Have you ever taken time off from your career for a family reason (i.e. childbirth, 
care of an elderly relative, etc.). I have found that many of the women perceived as successful in public relations have miserable personal lives and very little personal security. In the end, is that success?”

Future research can examine not only female public relations executives in their work environments, but also in their personal lives. Does a successful woman forego marriage and a family for her career? Can she successfully manage a career and a family? It would be interesting to see how many successful female public relations executives are either single or single parents compared to their male counterparts. 


\section{SELECTED BIBLIOGRAPHY}

Aldoory, Linda, “The Language of Leadership for Female Public Relations Professionals,” Journal of Public Relations Research 10, 2 (1998): 73-102.

Aldoory, Linda and Elizabeth Toth, "Gender Discrepancies in a Gendered Profession: A Developing Theory for Public Relations,” Journal of Public Relations Research 14, 2 (2002): 103-127.

Angrist, S.A., “The Study of Sex Roles,” Journal of Social Issues 15 (1969): 215-232.

Babbie, E.R., The Practice of Social Research, $9^{\text {th }}$ Edition. Belmont, CA: Wadsworth/Thompson Learning, 2000.

Bates, D., “A Concern: Will Women Inherit the Profession?” Public Relations Journal 29 (1983): 6.

Bem, S.L., Probing the Problem of Androgny. Boston: Little, Brown, 1976.

Choi, Youjin and Linda Childers Hon, "The Influence of Gender Composition in Powerful Positions on Public Relations Practitioners' Gender-Related Perceptions,” Journal of Public Relations Research 14, 2 (2002): 233.

Cline, Carolyn Garrett, Toth, Elizabeth Lance Toth, Judy VanSlyke Turk, Lynne Masel Walters, Nancy Johnson and Hank Smith, The Velvet Ghetto: The Impact of the Increasing Percentage of Women in Public Relations and Business Communication. San Francisco: IABC Foundation, 1986.

Dozier, David M., “Breaking the Public Relations Glass Ceiling,” Public Relations Review 14, 3 (Fall 1998): 7.

Gillis, Tamara and Frank Wylie, "Two Views on 'Women in Public Relations: How Gender Influences Practice’,” Communication World 18, (June/July 2001): 44-46.

Gower, Karla H., “Rediscovering Women in Public Relations,” Journalism History 27, 1 (Spring 2001): 14-22.

Grunig, Larissa A., Elizabeth L Toth. and Linda Childers Hon, "Feminist Values in Public Relations,” Journal of Public Relations Research 12, 1 (January 2000): 49-69.

Grunig, J.E., Excellence in Public Relations and Communication Management. Hillsdale, NJ: Lawrence Erlbaum Associates, Inc., 1992. 
Kohlberg, L., The Development of Sex Differences. Stanford, CA: Stanford University Press, 1966.

Kramarae, C. and P.A. Treichler, A Feminist Dictionary. London: Pandora, 1985.

Odendahl, Teresa and Michael O’Neill, Women \& Power in the Nonprofit Sector. CA: JosseyBass Inc., 1994.

Powell, G.N., Women and Men in Management. Newbury Park, CA: Sage, 1988.

Shapiro, Ann-Louise, "Introduction: History and Feminist Theory, or Talking Back to the Beadle,” History \& Theory 31, 4 (December 1992): 1-15.

Smith, R., "Women in Public Relations,” Public Relations Journal 24 (1968).

Spence, J.T. and R.L. Helmreich, "Masculine Instrumentality and Feminine Expressiveness: Their Relationship with Separate Role Attributes and Behaviors,” Psychology of Women Quarterly 5 (1980): 147.

Taft, Heidi P., "Have Times Changed? IABC Research Foundation's 'The Velvet Ghetto’ Study Revisited,” Communication World 20, 2 (February/March 2003): 10.

The American Heritage Dictionary. $4^{\text {th }}$ ed. New York, NY: Dell Publishing/Random House, 2001.

Toth, Elizabeth Lance, "Making Peace with Gender Issues in Public Relations,” Public Relations Review 14, 3 (Fall 1998): 37.

Velasquez, Manuel, Philosophy: A Tutorial Reader. Belmont, CA: Wadsworth, 1991.

Wimmer, Roger D. and Joseph R. Dominick, Mass Media Research. $7^{\text {th }}$ ed. Belmont, CA: Wadsworth/Thomas Learning, 2003. 


\section{APPENDIX 1}

Dear Public Relations Executive:

I am a female graduate student at the Perley Issac Reed School of Journalism at West Virginia University, surveying female public relations executives under the supervision of Dr. Terry Wimmer and Dr. Ivan Pinnell. The purpose of my study is to explore female public relations executives in the corporate and nonprofit sectors. Please keep in mind I am only asking questions about feminine and masculine values in public relations.

Please send your responses no later than March 20. Responses can be sent to me via the following email address: sthomas3@mix.wvu.edu

Please help me with my research! The survey should take less than ten minutes. Your identity will be kept confidential at all times and you're free to withdraw at any point in this study. Thank you for your time. If you're interested in a report on the findings of this study, let me know at the end of your response.

Best,

Sarah Thomas

P.I. Reed School of Journalism

West Virginia University

sthomas3@mix.wvu.edu 


\section{Questionnaire}

Thank you for participating in this survey. First of all, I would like to ask you some questions about yourself. Please put an X next to your answer.

V1. How many years have you worked full-time in the public relations profession?
( ) Less than 1 year
( ) 1-5 years
( ) 6-10 years
( ) 11-15 years
( ) 16-20 years
( ) 21-25 years
( ) 26-30 years
( ) $31+$ years

V2. How many years have you been a member of the Public Relations Society of America?
( ) Less than 1 year
( ) 1-5 years
( ) 6-10 years
( ) 11-15 years
( ) 16-20 years
( ) $21+$ years

V3. How much is your annual salary?
( ) $\$ 0-\$ 15,000$
( ) $\$ 16,000-\$ 25,000$
( ) $\$ 26,000-\$ 35,000$
( ) $\$ 36,000-\$ 45,000$
( ) $\$ 46,000-\$ 55,000$
( ) $\$ 56,000-\$ 65,000$
( ) $\$ 66,000-\$ 75,000$
( ) $\$ 76,000-\$ 85,000$
( ) $\$ 86,000-\$ 95,000$
( ) $\$ 96,000+$

V4. Please mark the sector in which you work.
( ) Corporate
( ) Nonprofit
( ) Agency

V5. Please mark your highest level of education.
( ) High School
( ) Undergraduate Degree 

( ) Masters Degree
( ) Doctoral Degree
( ) Professional Degree

The following questions include a series of terms often used to characterize people. They suggest different feelings, some positive, some negative. First, I'd like to ask you how much each attribute is characteristic of men.

Please mark an X under Strongly Agree, Agree, Disagree, or Strongly Disagree.
SA
A
D SD

V6. Aggressive

V7. Assertive

V8. Communal

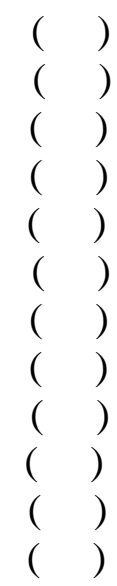

$\begin{array}{ll}( & \\ ( & ) \\ ( & ) \\ ( & ) \\ ( & ) \\ ( & ) \\ ( & ) \\ ( & ) \\ ( & ) \\ ( & ) \\ ( & ) \\ ( & \end{array}$

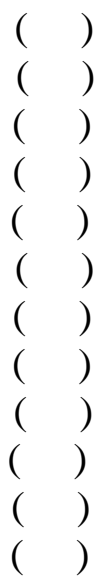

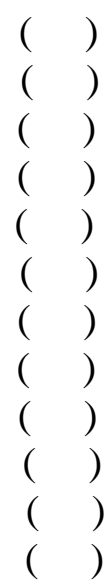

Now, I would like to ask you how much you think each attribute is characteristic of women.

Again, please mark an X under Strongly Agree, Agree, Disagree, or Strongly Disagree.

\section{SA}

A

$\mathrm{D}$

SD

V18. Aggressive

V19. Assertive

$(\quad)$
$(\quad)$
$(\quad)$
$(\quad)$

. Communal

V21. Competitive

V22. Cooperative

V23. Dominant

V24. Independent

( )

V25. Interconnected

V26. Perceptive

V27. Self-Reliant ( )

V28. Sensitive ( )

V29. Understanding ( )

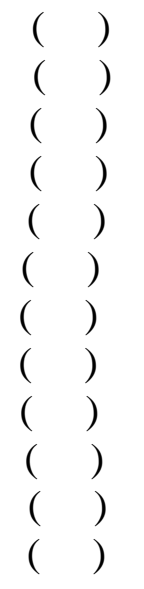
( )
( )
( )
( )
( )
( )
( )
( )
( )
( )
( )

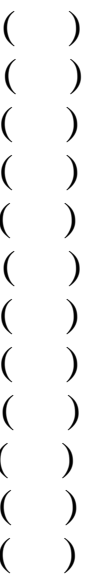


Finally, please tell me whether you agree or disagree with the following statements. Please mark an X under Strongly Agree, Agree, Disagree, or Strongly Disagree.
SA
A
D
SD

V30. The attributes of a good public relations executive are self-reliant, aggressive, and independent.
( )
( )
( )
( )

V31. The technician, or non-management, role is consistent with the feminine traits.
( )
( )
( )
( )

V32. Our society and culture place higher importance on male attributes than female attributes.

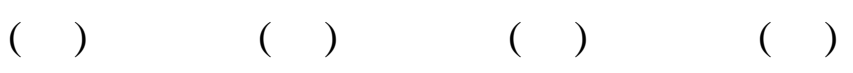

V33. The higher social and economic status of men in our society is a result of society placing higher importance on male attributes than female attributes.

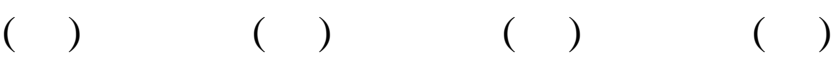

V34. Women have a relatively easier time elevating to positions of leadership in nonprofit organizations than corporate organizations.

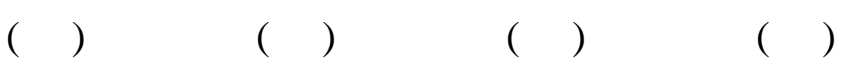

V35. It is easier for women to enter executive and managerial jobs in sectors in which they predominately supervise women.

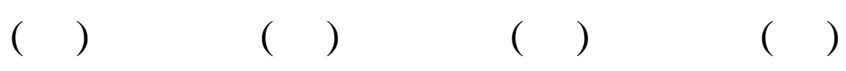

V36. I feel more comfortable working with women rather than men.

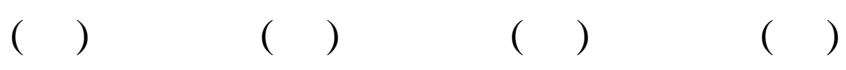

V37. To be a successful public relations executive, women must suppress their feminine traits.

$\left(\begin{array}{llll} & (2) & (\end{array}\right)$


V38. To be a successful public relations executive, women must display more masculine qualities.

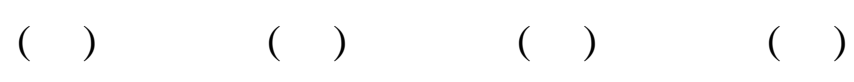

V39. Women are better public relations practitioners than men.

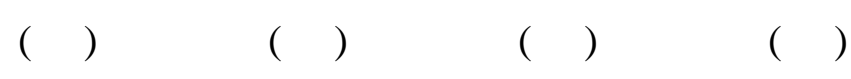

V40. Women who are sensitive, honest, and tolerant are more likely to become executives in the nonprofit sector.

$$
\left(\begin{array}{llll} 
& (\quad) & (
\end{array}\right)
$$

V41. Women who are aggressive, dominant, and competitive are more likely to become executives in the corporate sector.

$$
\left(\begin{array}{llll} 
& (
\end{array}\right) \quad(\quad)
$$

V42. I feel more respected when I am assertive, dominant, and self-confident while performing managerial tasks.
$(\quad)$
$(\quad)$
$(\quad)$
$(\quad)$

Comments/Concerns:

Thanks again. Please send your survey to me at sthomas3@mix.wvu.edu. 